OPEN ACCESS

Edited by:

Antonella Gasbarri,

University of L'Aquila, Italy

Reviewed by:

Sean Commins,

Maynooth University, Ireland

Thomas Van Groen,

University of Alabama at Birmingham,

United States

*Correspondence:

Miroljub Popović

miroljub@um.es

Specialty section:

This article was submitted to

Neuropharmacology,

a section of the journal

Frontiers in Pharmacology

Received: 29 June 2017 Accepted: 09 August 2017

Published: 23 August 2017

Citation:

Giménez De Béjar V, Caballero Bleda M, Popović N and Popović M (2017) Verapamil Blocks Scopolamine

Enhancement Effect on Memory Consolidation in Passive Avoidance

Task in Rats.

Front. Pharmacol. 8:566.

doi: 10.3389/fphar.2017.00566

\section{Verapamil Blocks Scopolamine Enhancement Effect on Memory Consolidation in Passive Avoidance Task in Rats}

\author{
Verónica Giménez De Béjari,2, María Caballero Bleda ${ }^{2,3}$, Natalija Popović ${ }^{2,3}$ and \\ Miroljub Popović2,3*
}

\begin{abstract}
${ }^{1}$ Department of Neurology, Hospital Quirónsalud Murcia, Murcia, Spain, ${ }^{2}$ Instituto Murciano de Investigación Biosanitaria Virgen de la Arrixaca, Murcia, Spain, ${ }^{3}$ Department of Human Anatomy and Psychobiology, Faculty of Medicine, University of Murcia, Murcia, Spain
\end{abstract}

Our recent data have indicated that scopolamine, a non-selective muscarinic receptor antagonist, improves memory consolidation, in a passive avoidance task, tested in rats. It has been found that verapamil, a phenylalkylamine class of the L-type voltagedependent calcium channel antagonist, inhibits $[3 \mathrm{H}] \mathrm{N}$-methyl scopolamine binding to M1 muscarinic receptors. However, there are no data about the effect of verapamil on memory consolidation in the passive avoidance task, in rats. The purpose of the present study was to examine the effects of verapamil $(0.5,1.0,2.5,5.0$, 10, or $20 \mathrm{mg} / \mathrm{kg}$ i.p.) as well as the interaction between scopolamine and verapamil on memory consolidation in the step-through passive avoidance task, in Wistar rats. Our results showed that verapamil (1.0 and $2.5 \mathrm{mg} / \mathrm{kg}$ ) administered immediately after the acquisition task significantly increased the latency of the passive avoidance response, on the $48 \mathrm{~h}$ retested trial, improving memory consolidation. On the other hand, verapamil in a dose of $5 \mathrm{mg} / \mathrm{kg}$, that per se does not affect memory consolidation, significantly reversed the memory consolidation improvement induced by scopolamine $(1 \mathrm{mg} / \mathrm{kg}$, i.p., administered immediately after verapamil treatment) but did not change the passive avoidance response in rats treated by an ineffective dose of scopolamine (30 mg/kg). In conclusion, the present data suggest that (1) the post-training administration of verapamil, dose-dependently, improves the passive avoidance response; (2) verapamil, in ineffective dose, abolished the improvement of memory consolidation effect of scopolamine; and (3) exists interaction between cholinergic muscarinic receptors and calcium homeostasis-related mechanisms in the consolidation of emotional memory.

Keywords: memory consolidation, passive avoidance, verapamil, scopolamine, rat

\section{INTRODUCTION}

The influx of $\mathrm{Ca}^{2++}$ through the L-type voltage-gated calcium channels (LVGCCs) promotes several molecular processes that are engaged in learning and memory (Singewald et al., 2015; BasOrth et al., 2016; Sachser et al., 2016; Michalak and Biala, 2017; Wiera et al., 2017). Age-related memory loss as well as memory impairment in neurodegenerative and psychiatric diseases has been related to the LVGCCs dysfunction with consequent dysregulation of calcium homeostasis 
(Barad, 2003; Thibault et al., 2007; Berger and Bartsch, 2014; Yoshimizu et al., 2015; Zanos et al., 2015).

Initially, LVGCCs antagonists, such as benzothiazapines (e.g., diltiazem); dihydropyridines (e.g., amlodipine, felodipine, isradipine, nicardipine, nifedipine, nimodipine, and nisoldipine), diphenylalkylamines (e.g., flunarizine), and phenylalkylamines (e.g., verapamil), were defined as vasodilator, antiarrhythmic, and antianginal agents (Godfraind, 2017). Nowadays, LVGCCs are recognized for the treatment of central nervous system disorders like bipolar disorder (Cipriani et al., 2016), epilepsy (Nicita et al., 2016), and headache (Tfelt-Hansen and Tfelt-Hansen, 2009) with perspective to be also used for the treatment of Parkinson's disease (Stayte and Vissel, 2014; Surmeier et al., 2017), mood disorders (Kabir et al., 2017), and dementia (Nimmrich and Eckert, 2013).

In comparison to other LVGCCs antagonists, verapamil effects on memory formation are highly inconsistent. Its effect is not only dependent on dose, duration of the treatment, and memory trace phase, but also on memory task performance and species. In mice, acute verapamil treatment improves acquisition in passive avoidance and elevated plus maze tasks (Biala et al., 2013; Michalak and Biala, 2017) while does not affect acquisition in conditioned avoidance response, T-maze, and linear maze tasks (Malekar et al., 1999; Quartermain and Garcia de Soria, 2001; Quartermain et al., 2001). It has been found that acute verapamil treatment impairs familiarity discrimination and perirhinal plasticity, in rats (Seoane et al., 2009). Rats exposed for prolonged period to a high dose of verapamil $(50 \mathrm{mg} / \mathrm{kg}$ ) impaired passive avoidance learning, while lower doses applied either acutely or chronically did not affect passive avoidance performance (Lazarova-Bakarova et al., 1997; Lashgari et al., 2006). The chronic verapamil treatment in rats does not modify acquisition but prejudices retention of the radial maze task (Borroni et al., 2000; Woodside et al., 2004).

Memory consolidation is a fragile part of memory traces that occurs immediately after a learning event and lasts for several hours. In this period, the synthesis of plasticity-related proteins and consequent changes in synaptic strength bring to long-term memory storage in the brain (McGaugh, 2000; Kandel, 2001). Previous studies based on pharmacological modulation of cholinergic transmission by scopolamine, nonselective antimuscarinic agent, reported that scopolamine either does not interrupt (Elrod and Buccafusco, 1988; Cruz-Morales et al., 1992; Roldán et al., 1997; Mishima et al., 2001), impairs (Doyle and Regan, 1993; Sigala et al., 1997; Murphy et al., 2001; Hefco et al., 2003; Foley et al., 2004; Gutierres et al., 2012; Popović et al., 2015), or even improves memory consolidation (Popović et al., 2015), in rats tested in the passive avoidance task. The improving effect was only obtained if scopolamine was administered within $6.5 \mathrm{~h}$ after learning and when animals were tested $48 \mathrm{~h}$ after acquisition (Popović et al., 2015). Systemic post-training treatment with verapamil impairs habituation in rats exposed to the open filed task (Popović et al., 2016), but in mice preserves memory consolidation in the passive avoidance (Quartermain et al., 1993; Masoudian et al., 2015) and improves retention in the linear maze and elevated plus maze tasks (Biala et al., 2013).
It has been suggested by Quartermain et al. (2001) that the lack of consistency in verapamil effects on memory formation could be due to its number of side effects. Verapamil shares a vasodilatory effect with other LVGCCs antagonists, but together with diltiazem expresses depressant effect on heart rate (van Zwieten and Pfaffendorf, 1993; Noll et al., 1998). Moreover, verapamil tends to suppress the activity of sympathetic nervous system (Noll et al., 1998). Besides, verapamil does not block only LVGCCs channels (being Cav1.2 channels more sensitive than the Cav1.3 ones), but also Cav2.1, Cav2.2, Cav2.3, and Cav3.2 channels too (Ishibashi et al., 1995; Cai et al., 1997; Dobrev et al., 1999; Tarabova et al., 2007; Kuryshev et al., 2014). It has been demonstrated that in several brain regions (e.g., cerebral cortex, hippocampus, and hypothalamus), verapamil acts as an antagonist of muscarinic (Baumgold, 1986; Popova et al., 1990), serotoninergic (Taylor and Defeudis, 1984; Adachi and Shoji, 1986; Green et al., 1990; Popova et al., 1991; Shad and Saeed, 2007), dopaminergic (Sitges and Guarneros, 1998), $\alpha$ - and $\beta$-adrenergic (Galzin and Langer, 1983; Staneva-Stoytcheva et al., 1990, 1992), and GABAergic receptors (Staneva-Stoytcheva et al., 1991). In contrast to dosedependent increase of serotonin and dopamine release, verapamil completely abolishes norepinephrine release in rat hippocampal synaptosomes (Sitges and Reyes, 1995). Aside from these actions on neurotransmission, verapamil is a standard P-glycoprotein inhibitor (Bendayan et al., 2002) and small conductance calciumactivated potassium channels (SK channel) antagonist (Tao et al., 2013).

The relationship between calcium homeostasis, cholinergic system activation and learning and memory, remains to be completely elucidated. Our previous studies indicated that acute and chronic verapamil treatment could ameliorate morphological, physiological, cognitive, and non-cognitive behavioral dysfunctions in rats with cholinergic depletion, suggesting possible relations between cholinergic function and calcium metabolism (Popović et al., 1997a,b,c, 1998a,b, 1999, 2006; Caballero-Bleda et al., 2001). Similarly, Sekhar et al. (2016) demonstrated that verapamil improves scopolamine-induced memory impairment in elevated plus maze and novel object recognition tests. Although evidence exists that verapamil, at the subthreshold, ineffective dose, significantly blocks the improving effect of nicotine on memory consolidation in the elevated plus maze task (Biala et al., 2013), there are no data whether verapamil can modify scopolamine effects on memory consolidation. The aim of the present study was to evaluate the effect of verapamil as well as the interaction between cholinergic muscarinic receptors and calcium homeostasis on memory consolidation, in the passive avoidance task, in rats.

\section{MATERIALS AND METHODS}

\section{Experimental Animals}

Experiments were carried out on male Wistar rats (200-250 g). The animals were housed in standard Makrolon cages on sawdust bedding. They were kept in an air-conditioned room $\left(20 \pm 1^{\circ} \mathrm{C}\right)$, at $30 \%$ humidity, and under a $12 \mathrm{~h}$ light/12 h dark cycle (lights 
on from 08:00 to 20:00 h). Food and tap water were available ad libitum. Before the passive avoidance performance, each rat was handled daily for 5 min during 1 week. The handling and the passive avoidance test were performed between 16:00 h and 20:00 h.

The animal maintenance and experiments were performed in accordance with the European Communities Council Directive of 24 November 1986 (86/609/EEC) and the guidelines issued by the Spanish Ministry of Agriculture, Fishing and Feeding (Royal Decree 1201/2005 of 21 October 2005). All procedures with animals were approved by the Animal Ethics Committee of the University of Murcia. Efforts were made to minimize animal suffering and the number of animals used.

\section{Drugs}

Verapamil and scopolamine hydrobromide were provided by Sigma, St. Louis, MO, United States. Saline solutions of verapamil $(0.5,1,2.5,5,10$, or $20 \mathrm{mg} / \mathrm{kg})$, scopolamine hydrobromide (1 $\mathrm{mg} / \mathrm{kg}$ and $30 \mathrm{mg} / \mathrm{kg}$ ), or their combination $(5 \mathrm{mg} / \mathrm{kg}$ of verapamil followed by $1 \mathrm{mg} / \mathrm{kg}$ of scopolamine) were administered intraperitoneally. Control animals were treated intraperitoneally with physiological saline at the dose of $1 \mathrm{ml} / \mathrm{kg}$ body weight.

\section{Passive Avoidance Test}

The passive avoidance testing was done in an automatically operated commercial Passive Avoidance Apparatus (stepthrough cage 7550; Ugo Basile, Comerio, Italy). The passive avoidance step-through cage was divided into two equal size compartments (insight dimension $22 \mathrm{~cm}$ long $\times 21 \mathrm{~cm}$ wide $\times 22 \mathrm{~cm}$ high, each): START (white and illuminated by a $24 \mathrm{~V}-10 \mathrm{~W}$ bulb) and ESCAPE (black and dark). The two compartments are divided by a partition which embodies an automatically operated sliding door at the floor level. On day 1 , each rat was exposed to the exploration trial, by placing it in the START chamber (door closed and shock disconnected) and allowed to explore it for 100 s. After that the door was opened, the rat was allowed to enter into the ESCAPE chamber, and when all four paws were in, the automated slide door was closed. The maximum latency to pass from the START to the ESCAPE compartment was set to $60 \mathrm{~s}$. After $10 \mathrm{~s}$, the rat was removed from the ESCAPE compartment and returned to its home cage. On day 2 (acquisition trial), when the rat entered into the ESCAPE compartment, the door was closed and a $1.0 \mathrm{~mA}$ shock was delivered for $5 \mathrm{~s}$. Ten seconds later on, the rat was removed from the ESCAPE compartment, drug administered (saline, verapamil, scopolamine, or verapamil followed by scopolamine treatment), and returned to its home cage. According to the latency period to enter into the ESCAPE compartment on day 1 and sensitivity to the shock (vocalization and jumping response) on day 2, the animals were assigned into 11 groups; thus, there were no significant differences between groups. Eight animals were assigned in each tested group. Forty-eight hours after the acquisition trial, the retention trial was carried out. The test was performed in a similar way to the acquisition trial, but no shock was given. The cage catch pan, grid floor, and side walls were cleaned with $70 \%$ ethanol before each animal was tested.
The most often cut-off times used in the passive avoidance test are 180,300 , and $600 \mathrm{~s}$. In the present study, the cut-off time for the entrance of the rat into the dark compartment was 9 min (maximum time allowed by the used apparatus). The longer cut-off time is when the individual differences become more apparent (Sahgal, 1993). Therefore, for better drug effect discrimination, three cut-off times $(180,300$, and $540 \mathrm{~s})$ were analyzed for each animal and group.

\section{Statistical Analysis}

The statistical analysis was made using the SPSS 19.0 statistical package. The data are presented as mean \pm standard error of the mean (SEM). The effects of verapamil or scopolamine on the step-through latency were analyzed with the one-way ANOVA, followed by the least significant difference (LSD) post hoc test. The two-tailed Student's $t$-test for independent samples was used to analyze the effect of combined verapamil and scopolamine treatments. Differences were considered statistically significant if $p<0.05$.

\section{RESULTS}

On the $48 \mathrm{~h}$ retention trial of the passive avoidance test, using a maximum cut-off time of $540 \mathrm{~s}$, the one-way ANOVA test showed significant dose-dependent effect of verapamil on the step-through latency $\left(F_{(6,49)}=2,483, p=0.036\right.$; Figure 1C). In animals treated with verapamil at the doses of 1 and $2.5 \mathrm{mg} / \mathrm{kg}$, the step-through latency on the $48 \mathrm{~h}$ retention trial was significantly higher in comparison to the groups treated with saline ( $p=0.037$ and $p=0.012$, respectively), verapamil in the dose of 0.5 ( $p=0.029$ and $p=0.009$, respectively) and $20 \mathrm{mg} / \mathrm{kg}(p=0.028$ and $p=0.009$, respectively). Moreover, animals treated with verapamil at the dose of $2.5 \mathrm{mg} / \mathrm{kg}$ showed higher step-through latency in comparison to the animals treated with verapamil at the dose of $10 \mathrm{mg} / \mathrm{kg}(p=0.05)$. Although employing a $300 \mathrm{~s}$ cut-off time, the one-way ANOVA test showed no significant dose-dependent effect of verapamil on the step-through latency $\left(F_{(6,49)}=1,512, p=0.194\right)$, there were significant differences between animals treated with verapamil in the dose of $2.5 \mathrm{mg} / \mathrm{kg}$ and animals treated with saline $(p=0.043)$, verapamil in the doses of 10 and $20 \mathrm{mg} / \mathrm{kg}(p=0.034$ and $p=0.040$, respectively; Figure 1B). Applying a 180 s cut-off time, the one-way ANOVA test showed no significant dose-dependent effect of verapamil on the step-through latency $\left(F_{(6,49)}=1,132\right.$, $p=0.358$; Figure 1A).

The one-way ANOVA test did not showed significant dosedependent effect of scopolamine on the step-through latency, utilizing 180,300 , and $540 \mathrm{~s}$ cut-off time $\left(F_{(2,21)}=0.472\right.$, $p=0.630 ; F_{(2,21)}=1,074, p=0.360$; and $F_{(2,21)}=2.995, p=0.72$, respectively) (Figures 2A-C). However, when evaluating at $540 \mathrm{~s}$ cut-off time, the step-through latency was significantly higher in animals treated with scopolamine in the dose of $1 \mathrm{mg} / \mathrm{kg}$, in comparison to those treated with saline and scopolamine in the dose of $30 \mathrm{mg} / \mathrm{kg}$ ( $p=0.045$ and $p=0.047$, respectively; Figure 2C). The animals treated by the combined treatment of scopolamine $(1 \mathrm{mg} / \mathrm{kg})$ and verapamil $(5 \mathrm{mg} / \mathrm{kg})$ significantly 

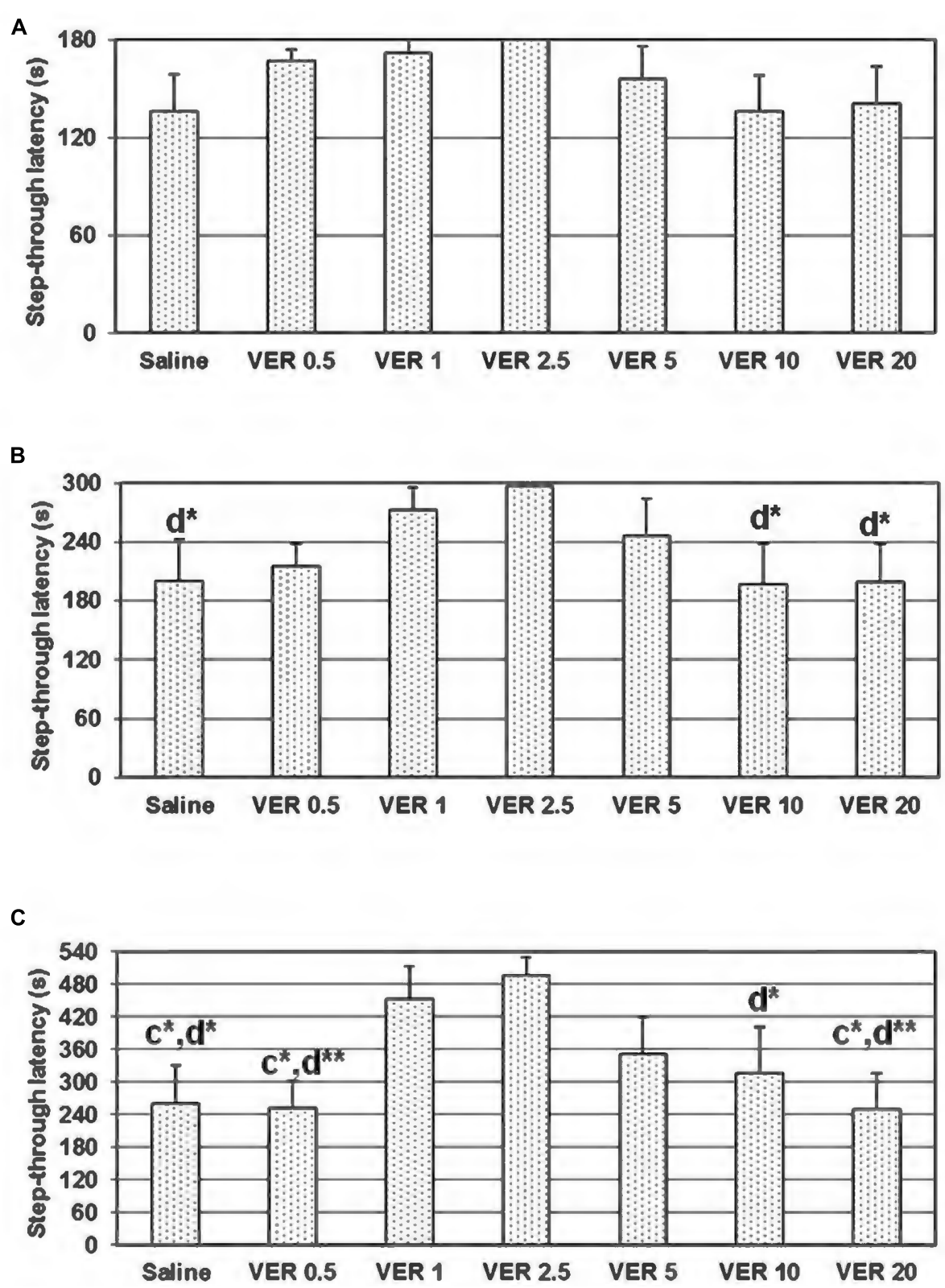

FIGURE 1 | Effect of $0.5,1,2.5,5,10$, and 20 mg/kg of verapamil (VER-0.5, VER-1, VER-2.5, VER-5, VER-10, and VER-20, respectively), administered i.p., immediately after the acquisition trial, on the $48 \mathrm{~h}$ retention trial, in the passive avoidance task, in conditions of 180 (A), 300 (B), and $540 \mathrm{~s}$ (C) cut-off latency. The data are presented as mean \pm standard error of the mean (SEM). C-compared to VER-1 and d-compared to VER $2.5 ;{ }^{*} p<0.05$, ${ }^{* *} p<0.01$.

reduced the step-through latency in comparison to the group treated only by scopolamine $(1 \mathrm{mg} / \mathrm{kg})(t=2.219$, $d f=14$, $p=0.044$; Figure 2C).

\section{DISCUSSION}

It has been demonstrated that verapamil treatment in the dose of $20 \mathrm{mg} / \mathrm{kg}$ does not modify, but that in the dose range from 1 to $10 \mathrm{mg} / \mathrm{kg}$ significantly improves consolidation of spatial memory in the linear maze task, in mice (Quartermain et al.,
2001). In the elevated plus maze task, only mid-doses used of verapamil ( 5 and $10 \mathrm{mg} / \mathrm{kg}$ ) display enhancement effect on spatial memory consolidation, in mice (Biala et al., 2013). The present data indicated that verapamil at the doses of 1 and $2.5 \mathrm{mg} / \mathrm{kg}$, but not at the doses of $0.5,5,10$, and $20 \mathrm{mg} / \mathrm{kg}$, improved memory consolidation of rats tested in passive avoidance task, confirming the inverted U-shape dose-response curve of its action on memory consolidation. In contrast to the present study, Quartermain et al. (2001) and Masoudian et al. (2015) found that the post-training treatment with verapamil $(1,2,10$, and $20 \mathrm{mg} / \mathrm{kg}$ and $1,2.5,5,10$, and $20 \mathrm{mg} / \mathrm{kg}$, respectively) did not 

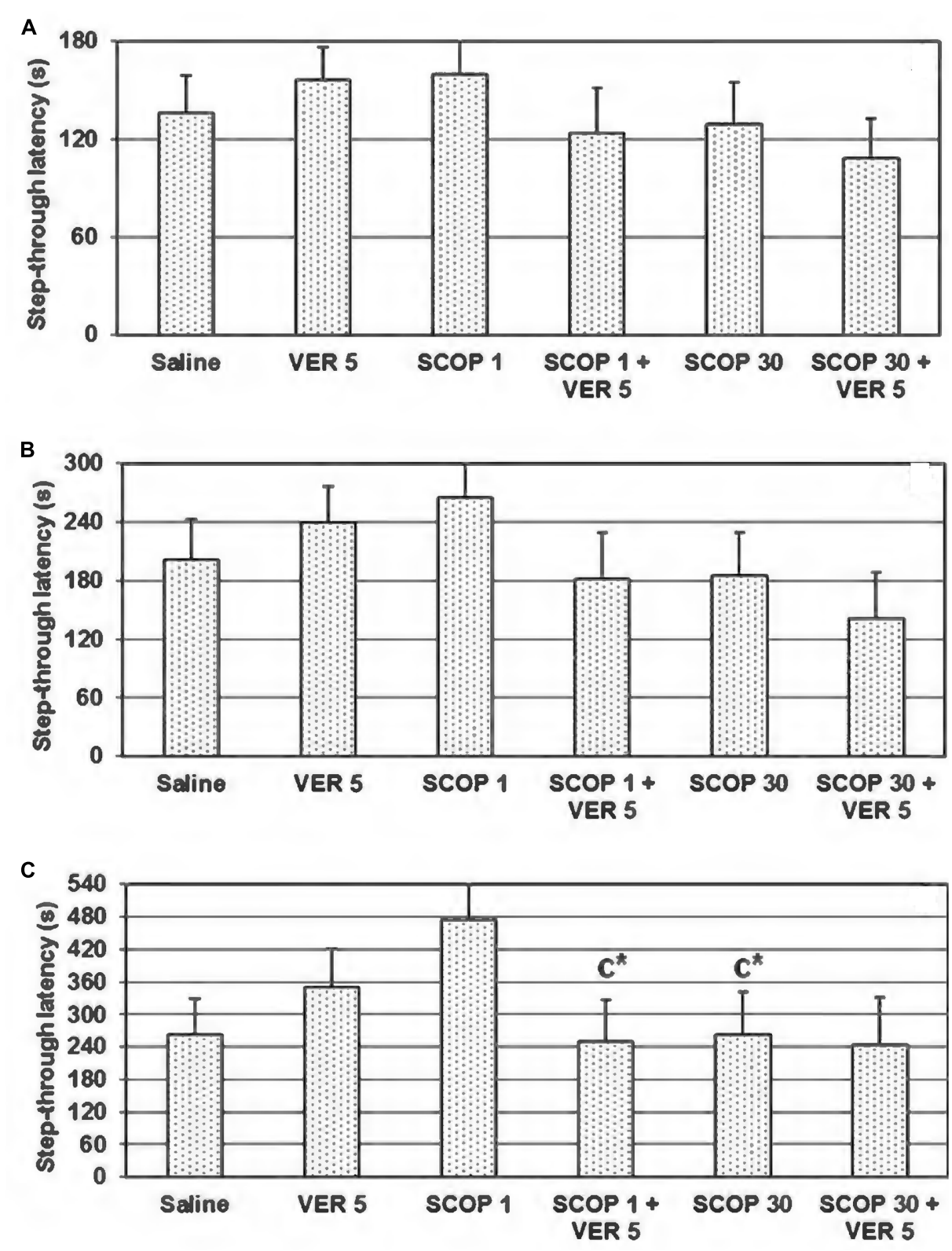

FIGURE 2 | Effect of combined verapamil (VER) $5 \mathrm{mg} / \mathrm{kg}$ and scopolamine (SCOP) (1 or $30 \mathrm{mg} / \mathrm{kg}$ ), administered i.p., immediately after the acquisition trial, on the $48 \mathrm{~h}$ retention trial, in the passive avoidance task in conditions of 180 (A), 300 (B), and $540 \mathrm{~s}$ (C) cut-off latency. Data are presented as mean \pm SEM. C-compared to SCOP- $1 ;{ }^{*} p<0.05$.

change the retention of the passive avoidance task in mice. The discrepancies between data obtained in passive avoidance studies could be attributed to the species utilized (mice vs. rats), shock intensity ( 0.1 or 0.5 vs. $1 \mathrm{~mA}$ ), duration of the shock ( 1 or 2 vs. $5 \mathrm{~s}$ ), acquisition-retention interval ( 24 or $48 \mathrm{~h}$ ), as well as the duration of the retention trial applied (400 vs. $540 \mathrm{~s}$ ).

Glick and Zimmerberg (1971) and Rush (1988) showed that scopolamine in higher dose (10-30 $\mathrm{mg} / \mathrm{kg})$ impaired memory consolidation in mice tested in the passive avoidance task. The same authors demonstrated that the dose-dependent impairment is related to the duration of the cut-off latency
$(180,300$, or $600 \mathrm{~s})$, such as longer cut-off latency and lower scopolamine dose are necessary to induce memory impairment. To discard the influence of the cut-off latency time, in the present study we also performed statistical analyses with two shorter frequently used cut-off latency periods (180 and $300 \mathrm{~s}$ ). Our data suggest that verapamil administered in the dose of $2.5 \mathrm{mg} / \mathrm{kg}$ significantly improved memory consolidation in the passive avoidance task, when 300 and 540 s cut-off time were utilized. In contrast, scopolamine in the dose of $1 \mathrm{mg} / \mathrm{kg}$ improved memory consolidation when 540 s (Popović et al., 2015), but not when shorter (180 and 300 s) cut-off time was employed. 
On the other hand, $30 \mathrm{mg} / \mathrm{kg}$ of scopolamine (independent of the cut-off latency time) applied in the present study, as well as $50 \mathrm{mg} / \mathrm{kg}$ of it, used by Anagnostaras et al. (1999), did not modify memory consolidation in rats tested in the passive avoidance and fear condition tasks, respectively. These results imply that optimal level of cholinergic neuronal firing, crucial for memory formation, is not only task (Hasselmo and McGaughy, 2004; Hasselmo and Sarter, 2011) but could be also species depending.

The mechanism by which verapamil facilitates or impairs consolidation of emotional memory is still unclear. Findings obtained in Cav1.2 knockout mice argue against the role of the Cav1.2 channels in the consolidation of emotional memory (McKinney et al., 2008). On the other hand, impaired ability of Cav1.3 knockout mice to consolidate contextually conditioned fear but with preserved consolidation in the hidden platform version of the Morris water maze test reveals that the deficits observed in these mice are the result of a disruption of neuronal function within the amygdala (McKinney and Murphy, 2006). Given an inverted U-shape dose-response curve of the verapamil action, Biala et al. (2013) proposed that its action could be due to modulation rather than a complete blockade of LVGCCs (Biala et al., 2013). The facts that: (1) CaV1.2 subtypes are blocked at much lower doses of verapamil in comparison with the CaV1.3 subtypes (Tarabova et al., 2007); (2) higher doses of LVGCCs blockers are required to effectively inhibit brain CaV1.2 and CaV1.3 channels (Helton et al., 2005; Zamponi et al., 2015); and (3) hypotension could improve memory consolidation in the passive avoidance task (Haile et al., 2012), suggest the possibility that outcomes of low doses verapamil treatment, on the passive avoidance consolidation, could be attributed to its effect on the cardiovascular system rather than to the effect on neurons and most likely modulated via CaV1.2 subtypes of LVGCCs.

In view of the facts that verapamil can block SK channel (Tao et al., 2013) and that the blockade of SK2 channels, immediately after the training, enhanced contextual fear memory (Murthy et al., 2015), it could be expected that the effect of verapamil is partially due to the action on these channels, too. On the other side, verapamil expresses both $\alpha_{1}$ and $\alpha_{2}$ adrenergic receptor blocking activity (Müller and Noack, 1988) and blocking of the $\alpha_{2}$ adrenergic receptor subtype improves memory consolidation in the passive avoidance task (Ferry et al., 2015).

Other potential mechanism of verapamil effects on memory consolidation could be related to its antagonistic action on cholinergic receptors. Biala et al. (2013) demonstrated that

\section{REFERENCES}

Adachi, H., and Shoji, T. (1986). Characteristics of the inhibition of ligand binding to serotonin receptors in rat brain membranes by verapamil. Jpn. J. Pharmacol. 41, 431-435. doi: 10.1254/jjp.41.431

Anagnostaras, S. G., Maren, S., Sage, J. R., Goodrich, S., and Fanselow, M. S. (1999). Scopolamine and Pavlovian fear conditioning in rats: dose-effect analysis. Neuropsychopharmacology 21, 731-744. doi: 10.1016/S0893-133X(99) 00083-4

Barad, M. (2003). Later developments: molecular keys to age-related memory impairment. Alzheimer Dis. Assoc. Disord. 17, 168-176. doi: 10.1097/00002093200307000-00009 verapamil, at the subthreshold, ineffective dose $(2.5 \mathrm{mg} / \mathrm{kg})$, significantly blocked the improving effect of nicotine $(0.035 \mathrm{mg} / \mathrm{kg})$ on memory consolidation, in the elevated plus maze task. Similarly, the present data showed that verapamil, in ineffective dose $(5 \mathrm{mg} / \mathrm{kg})$, abolished the improvement of memory consolidation effect of $1 \mathrm{mg} / \mathrm{kg}$ of scopolamine but did not change the passive avoidance response when ineffective dose of scopolamine $(30 \mathrm{mg} / \mathrm{kg})$ was used. Considering that nicotinic antagonists can block the scopolamine effect of memory formation (Newman and Gold, 2016) and that verapamil inhibited $\left[{ }^{3} \mathrm{H}\right] \mathrm{N}$-methyl scopolamine binding to M1 muscarinic receptors in the rat brain cortex (Baumgold, 1986), further studies are need to determine the cascade of verapamil action on memory consolidation.

\section{CONCLUSION}

As far as we know, the present data represent the first demonstration that verapamil dose-dependently improves memory consolidation of the passive avoidance task in rats, and that exists interaction between cholinergic muscarinic receptors and calcium homeostasis, on memory consolidation.

\section{AUTHOR CONTRIBUTIONS}

VG, MC, NP, and MP contributed to the design of the study, wrote the protocol, and managed the literature searches; VG, NP, and MP performed the experiments and undertook the statistical analysis; and VG, MC, NP, and MP contributed to drafting the work and have approved the final manuscript.

\section{FUNDING}

Funding for this study was provided by the Health Council of Murcia Region, Spain (MC), the Spanish Ministry of Economy and Competitiveness (BFU2014-57516-P; LPL, JLF), and the European Regional Development Fund (EFDR; LPL). The funding source had no further role in the study design; in the collection, analysis, and interpretation of the data; in the writing of the report; or in the decision to submit the paper for publication.

Bas-Orth, C., Tan, Y. W., Oliveira, A. M., Bengtson, C. P., and Bading, H. (2016). The calmodulin-binding transcription activator CAMTA1 is required for longterm memory formation in mice. Learn. Mem. 23, 313-321. doi: 10.1101/lm. 041111.115

Baumgold, J. (1986). Effects of verapamil on the binding characteristics of muscarinic receptor subtypes. Eur. J. Pharmacol. 126, 151-154. doi: 10.1016/ 0014-2999(86)90752-1

Bendayan, R., Lee, G., and Bendayan, M. (2002). Functional expression and localization of P-glycoprotein at the blood brain barrier. Microsc. Res. Tech. 57, 365-380. doi: 10.1002/jemt.10090

Berger, S. M., and Bartsch, D. (2014). The role of L-type voltage-gated calcium channels Cav1.2 and Cav1.3 in normal and pathological 
brain function. Cell Tissue Res. 357, 463-476. doi: 10.1007/s00441-0141936-3

Biala, G., Kruk-Slomka, M., and Jozwiak, K. (2013). Influence of acute and chronic calcium channel antagonists on the acquisition and consolidation of memory and nicotine-induced cognitive effects in mice. Naunyn-Schmiedebergs Arch. Pharmacol. 386, 651-664. doi: 10.1007/s00210-013-0866-Z

Borroni, A. M., Fichtenholtz, H., Woodside, B. L., and Teyler, T. J. (2000). Role of voltage-dependent calcium channel long-term potentiation (LTP) and NMDA LTP in spatial memory. J. Neurosci. 20, 9272-9276.

Caballero-Bleda, M., Redondo-Aniorte, F. J., Aldeguer-Montiel, A., Popović, N., Popović, M., and Puelles, L. (2001). NADPH-diaphorase activity in the frontal cortex of NBM-lesioned rats treated with verapamil. Neurosci. Res. Commun. 28, 115-122. doi: 10.1002/nrc.1011

Cai, D., Mulle, J. G., and Yue, D. T. (1997). Inhibition of recombinant $\mathrm{Ca}^{2+}$ channels by benzothiazepines and phenylalkylamines: class-specific pharmacology and underlying molecular determinants. Mol. Pharmacol. 51, $872-881$.

Cipriani, A., Saunders, K., Attenburrow, M. J., Stefaniak, J., Panchal, P., Stockton, S., et al. (2016). A systematic review of calcium channel antagonists in bipolar disorder and some considerations for their future development. Mol. Psychiatry 21, 1324-1332. doi: 10.1038/mp.2016.86

Cruz-Morales, S. E., Duran-Arevalo, M., Diaz Del Guante, M. A., Quirarte, G., and Prado- Alcala, R. A. (1992). A threshold for the protective effect of overreinforced passive avoidance against scopolamine-induced amnesia. Behav. Neural Biol. 57, 256-259. doi: 10.1016/0163-1047(92)90248-3

Dobrev, D., Milde, A. S., Andreas, K., and Ravens, U. (1999). The effects of verapamil and diltiazem on $\mathrm{N}$-, P- and Q-type calcium channels mediating dopamine release in rat striatum. Br. J. Pharmacol. 127, 576-582. doi: 10.1038/ sj.bjp.0702574

Doyle, E., and Regan, C. M. (1993). Cholinergic and dopaminergic agents which inhibit a passive avoidance response attenuate the paradigm-specific increases in NCAM sialylation state. J. Neural Transm. Gen. Sect. 92, 33-49. doi: 10.1007/ BF01245160

Elrod, K., and Buccafusco, J. J. (1988). An evaluation of the mechanism of scopolamine-induced impairment in two passive avoidance protocols. Pharamacol. Biochem. Behav. 29, 15-21. doi: 10.1016/0091-3057(88)90267-5

Ferry, B., Parrot, S., Marien, M., Lazarus, C., Cassel, J. C., and McGaugh, J. L. (2015). Noradrenergic influences in the basolateral amygdala on inhibitory avoidance memory are mediated by an action on $\alpha 2$-adrenoceptors. Psychoneuroendocrinology 51, 68-79. doi: 10.1016/j.psyneuen.2014.09.010

Foley, A. G., Murphy, K. J., Hirst, W. D., Gallagher, H. C., Hagan, J. J., Upton, N., et al. (2004). The 5-HT6 receptor antagonist SB-271046 reverses scopolaminedisrupted consolidation of a passive avoidance task and ameliorates spatial task deficits in aged rats. Neuropsychopharmacology 29, 93-100. doi: 10.1038/sj.npp. 1300332

Galzin, A. M., and Langer, S. Z. (1983). Presynaptic alpha 2-adrenoceptor antagonism by verapamil but not by diltiazem in rabbit hypothalamic slices. Br. J. Pharmacol. 78, 571-577. doi: 10.1111/j.1476-5381.1983.tb08817.x

Glick, S. D., and Zimmerberg, B. (1971). Comparative learning impairment and amnesia by scopolamine, phencyclidine, and ketamine. Psychon. Sci. 25, 165-166. doi: 10.3758/BF03332487

Godfraind, T. (2017). Discovery and development of calcium channel blockers. Front. Pharmacol. 8:286. doi: 10.3389/fphar.2017.00286

Green, A. R., DeSouza, R. J., Davies, E. M., and Cross, A. J. (1990). The effects of $\mathrm{Ca}^{2+}$ antagonists and hydralazine on central 5-hydroxytryptamine biochemistry and function in rats and mice. Br. J. Pharmacol. 99, 41-46. doi: 10.1111/j.1476-5381.1990.tb14651.x

Gutierres, J. M., Carvalho, F. B., Schetinger, M. R. C., Rodrigues, M. V., Schmatz, R., Pimentel, V. C., et al. (2012). Protective effects of anthocyanins on the ectonucleotidase activity in the impairment of memory induced by scopolamine in adult rats. Life Sci. 91, 1221-1228. doi: 10.1016/j.lfs.2012.09.013

Haile, M., Galoyan, S., Li, Y. S., Cohen, B. H., Quartermain, D., Blanck, T., et al. (2012). Nimodipine-induced hypotension but not nitroglycerin-induced hypotension preserves long- and short-term memory in adult mice. Anesth. Analg. 114, 1034-1041. doi: 10.1213/ANE.0b013e31824b2b05

Hasselmo, M. E., and McGaughy, J. (2004). High acetylcholine levels set circuit dynamics for attention and encoding and low acetylcholine levels set dynamics for consolidation. Prog. Brain Res. 145, 207-231. doi: 10.1016/S0079-6123(03) 45015-2

Hasselmo, M. E., and Sarter, M. (2011). Modes and models of forebrain cholinergic neuromodulation of cognition. Neuropsychopharmacology 36, 52-73. doi: 10.1038/npp.2010.104

Hefco, V., Yamada, K., Hefco, A., Hritcu, L., Tiron, A., Olariu, A., et al. (2003). Effects of nicotine on memory impairment induced blockade of muscarinic, nicotinic and dopamine D2 receptors in rats. Eur. J. Pharmacol. 474, 227-232. doi: 10.1016/S0014-2999(03)02034-X

Helton, T. D., Xu, W., and Lipscombe, D. (2005). Neuronal L-type calcium channels open quickly and are inhibited slowly. J. Neurosci. 25, 10247-10251. doi: 10.1523/JNEUROSCI.1089-05.2005

Ishibashi, H., Yatani, A., and Akaike, N. (1995). Block of P-type $\mathrm{Ca}^{2+}$ channels in freshly dissociated rat cerebellar Purkinje neurons by diltiazem and verapamil. Brain Res. 695, 88-91. doi: 10.1016/0006-8993(95)00815-8

Kabir, Z. D., Martínez-Rivera, A., and Rajadhyaksha, A. M. (2017). From gene to behavior: L-type calcium channel mechanisms underlying neuropsychiatric symptoms. Neurotherapeutics 14, 588-613. doi: 10.1007/s13311-017-0532-0

Kandel, E. R. (2001). The molecular biology of memory storage: a dialogue between genes and synapses. Science 294, 1030-1038. doi: 10.1126/science.1067020

Kuryshev, Y. A., Brown, A. M., Duzic, E., and Kirsch, G. E. (2014). Evaluating state dependence and subtype selectivity of calcium channel modulators in automated electrophysiology assays. Assay Drug Dev. Technol. 12, 110-119. doi: 10.1089/adt.2013.552

Lashgari, R., Motamedi, F., Zahedi Asl, S., Shahidi, S., and Komaki, A. (2006). Behavioral and electrophysiological studies of chronic oral administration of L-type calcium channel blocker verapamil on learning and memory in rats. Behav. Brain Res. 171, 324-328. doi: 10.1016/j.bbr.2006.04.013

Lazarova-Bakarova, M. B., Stancheva, S., Petkova, B., Genkova-Papasova, M., Alova, L., Boyanova, E., et al. (1997). Effects of beta-adrenoceptor blocker pindolol, calcium antagonist verapamil and their combination on retention in step-down- and shuttle-box-trained rats and on brain biogenic monoamines. J. Physiol. Paris 91, 301-305. doi: 10.1016/S0928-4257(97)82410-2

Malekar, A. R., Balsara, J. J., and Gaonkar, R. K. (1999). Effects of verapamil on dopamine dependent behaviours in rats. Indian J. Physiol. Pharmacol. 43, 44-52.

Masoudian, N., Masoudian, N., Pour, A. R., Vafaiee, A. A., Andalib, S., and Vaseghi, G. (2015). Evaluation effects of verapamil as a calcium channel blocker on acquisition, consolidation and retrieval of memory in mice. J. Chem. Health Risks 5, 99-104.

McGaugh, J. L. (2000). Memory-a century of consolidation. Science 287, 248-251. doi: $10.1126 /$ science.287.5451.248

McKinney, B. C., and Murphy, G. G. (2006). The L-type voltage-gated calcium channel Cav1.3 mediates consolidation, but not extinction, of contextually conditioned fear in mice. Learn. Mem. 13, 584-589. doi: 10.1101/lm.279006

McKinney, B. C., Sze, W., White, J. A., and Murphy, G. G. (2008). L-type voltagegated calcium channels in conditioned fear: a genetic and pharmacological analysis. Learn. Mem. 15, 326-334. doi: 10.1101/lm.893808

Michalak, A., and Biala, G. (2017). Calcium homeostasis and protein kinase/phosphatase balance participate in nicotine-induced memory improvement in passive avoidance task in mice. Behav. Brain Res. 317, 27-36. doi: 10.1016/j.bbr.2016.09.023

Mishima, K., Egashira, N., Hirosawa, N., Fujii, M., Matsumoto, Y., Iwasaki, K., et al. (2001). Characteristics of learning and memory impairment induced by $\Delta 9$ tetrahydrocannabinol in rats. Jpn. J. Pharmacol. 87, 297-308. doi: 10.1254/jjp. 87.297

Müller, A., and Noack, E. (1988). Additive competitive interaction of verapamil and quinidine at alpha-adrenergic receptors of isolated cardiac guinea pig myocytes and human platelets. Life Sci. 42, 667-677. doi: 10.1016/0024-3205(88)90458-4

Murphy, K. J., Fox, G. B., Foley, A. G., Gallagher, H. C., OĆonnell, A., Griffin, A.M., et al. (2001). Pentyl-4-yn-valproic acid enhances both spatial and avoidance learning, and attenuates age-related NCAM-mediated neuroplastic decline within the rat medial temporal lobe. J. Neurochem. 78, 704-714. doi: 10.1046/j. 1471-4159.2001.00411.x

Murthy, S. R., Sherrin, T., Jansen, C., Nijholt, I., Robles, M., Dolga, A. M., et al. (2015). Small-conductance $\mathrm{Ca}^{2+}$-activated potassium type 2 channels regulate the formation of contextual fear memory. PLOS ONE 10:e0127264. doi: 10.1371/ journal.pone.0127264 
Newman, L. A., and Gold, P. E. (2016). Attenuation in rats of impairments of memory by scopolamine, a muscarinic receptor antagonist, by mecamylamine, a nicotinic receptor antagonist. Psychopharmacology 233, 925-932. doi: 10.1007/s00213-015-4174-9

Nicita, F., Spalice, A., Raucci, U., Iannetti, P., and Parisi, P. (2016). The possible use of the L-type calcium channel antagonist verapamil in drug-resistant epilepsy. Expert Rev. Neurother. 16, 9-15. doi: 10.1586/14737175.2016.1121097

Nimmrich, V., and Eckert, A. (2013). Calcium channel blockers and dementia. Br. J. Pharmacol. 169, 1203-1210. doi: 10.1111/bph.12240

Noll, G., Wenzel, R. R., Shaw, S., and Lüscher, T. F. (1998). Calcium antagonists and sympathetic nerve activation: are there differences between classes? J. Hypertens. Suppl. 16, S17-S24.

Popova, J., Staneva-Stoytcheva, D., Ivanova, E., and Tosheva, T. (1991). The longterm treatment with the $\mathrm{Ca}^{2+}$-antagonists nifedipine, verapamil, flunarizine and with the calmodulin antagonist trifluoperazine decreases the activity of 5HT1 receptors in rat cerebral cortex and hippocampus. Gen. Pharmacol. 22, 1147-1149. doi: 10.1016/0306-3623(91)90593-U

Popova, J., Staneva-Stoytcheva, D., and Mutafova, V. (1990). Effects of the $\mathrm{Ca}^{2+}$. antagonists nifedipine, verapamil, flunarizine and of the calmodulin antagonist trifluoperazine on muscarinic cholinergic receptors in rat cerebral cortex. Gen. Pharmacol. 21, 317-319. doi: 10.1016/0306-3623(90)90830-F

Popović, M., Caballero-Bleda, M., Popović, N., Bokonjić, D., and Dobrić, S. (1997a). Neuroprotective effect of chronic verapamil treatment on cognitive and noncognitive deficits in an experimental Alzheimer's disease in rats. Int. J. Neurosci. 92, 87-97.

Popović, M., Caballero-Bleda, M., Popović, N., Puelles, L., van Groen, T., and Witter, M. P. (2006). Verapamil prevents, in a dose-dependent way, the loss of ChAT-immunoreactive neurons in the cerebral cortex following lesions of the rat nucleus basalis magnocellularis. Exp. Brain Res. 170, 368-375. doi: 10.1007/s00221-005-0219-3

Popović, M., Giménez de Bejar, V., Popović, N., and Caballero-Bleda, M. (2015). Time course of scopolamine effect on memory consolidation and forgetting in rats. Neurobiol. Learn. Mem. 118, 49-55. doi: 10.1016/j.nlm.2014.11.006

Popović, M., Popović, N., Bokonjić, D., Dobrić, S., Ugrešić, N., and Kostić, V. S. (1998a). Effect of acute physostigmine and verapamil treatment on aggressive and depressive behavior in rats with lesioned nucleus basalis magnocellularis. Neurosci. Res. Commun. 23, 13-22. doi: 10.1002/(SICI)1520-6769(199807/08) 23:1<13::AID-NRC2>3.0.CO;2-O

Popović, M., Popović, N., and Caballero-Bleda, M. (1999). Effect of acute verapamil treatment on cold restraint-induced gastric lesions in rats with lesioned nucleus basalis magnocellularis. Neurosci. Res. Commun. 25, 163-171. doi: 10.1002/ (SICI) 1520-6769(199911/12)25:3<163::AID-NRC5>3.0.CO;2-4

Popović, M., Popović, N., Caballero-Bleda, M., and Puelles, L. (1998b). Effect of acute verapamil treatment on body temperatura in nucleus basalis magnocellularis-lesioned rats. Neurosci. Res. Commun. 23, 181-187. doi: 10. 1002/(SICI)1520-6769(199811/12)23:3<181::AID-NRC6>3.0.CO;2-E

Popović, M., Popović, N., Jovanova-Nešić, K., Bokonjić, D., Dobrić, S., Kostić, V. S., et al. (1997b). Effect of physostigmine and verapamil on active avoidance in an experimental model of Alzheimer's disease. Int. J. Neurosci. 90, 87-97.

Popović, M., Popović, N., Jovanova-Nešić, K., Bokonjić, D., Dobrić, S., and Rosić, N. (1997c). Open field behavior in nucleus basalis magnocellularis-lesioned rats treated with physostigmine and verapamil. Int. J. Neurosci. 91, 181-188.

Popović, N., Giménez de Bejar, V., Caballero-Bleda, M., and Popović, M. (2016). Verapamil parameter- and dose-dependently impairs memory consolidation in open field habituation task in rats. Front. Pharmacol. 7:539. doi: 10.3389/fphar. 2016.00539

Quartermain, D., and Garcia de Soria, V. (2001). The effects of calcium channel antagonists on short- and long-term retention in mice using spontaneous alternation behavior. Neurobiol. Learn. Mem. 76, 117-124. doi: 10.1006/nlme. 2000.3981

Quartermain, D., Garcia de Soria, V., and Kwan, A. (2001). Calcium channel antagonists enhance retention of passive avoidance and maze learning in mice. Neurobiol. Learn. Mem. 75, 77-90. doi: 10.1006/nlme.1999.3958

Quartermain, D., Hawxhurst, A., Ermita, B., and Puente, J. (1993). Effect of the calcium channel blocker amlodipine on memory in mice. Behav. Neural Biol. 60, 211-219. doi: 10.1016/0163-

Roldán, G., Bolaños-Badillo, E., González-Sánchez, H., Quirarte, G. L., and PradoAlcalá, R. A. (1997). Selective M1 muscarinic receptor antagonists disrupt memory consolidation of inhibitory avoidance in rats. Neurosci. Lett. 230, 93-96. doi: 10.1016/S0304-3940(97)00489-8

Rush, D. K. (1988). Scopolamine amnesia of passive avoidance: a deficit of information acquisition. Behav. Neural Biol. 50, 255-274. doi: 10.1016/S01631047(88)90938-7

Sachser, R. M., Santana, F., Crestani, A. P., Lunardi, P., Pedraza, L. K., Quilifeldt, J. A., et al. (2016). Forgetting of long-term memory requires activation of NMDA receptors, L-type voltaje-dependent $\mathrm{Ca}^{2+}$-channels, and calcineurin. Sci. Rep. 6:22771. doi: 10.1038/srep22771

Sahgal, A. (1993). "Passive avoidance procedures," in Behavioural Neuroscience. A Practical Approach, Vol. 1, ed. A. Sahgal (Oxford: IRL Press), 49-56.

Sekhar, D. S., Shwetha, B. K., Haimavathi, B., and Vikram, P. (2016). The effect of calcium channel blockers against scopolamine induced cognitive impairment and oxidative stress. Int. J. Basic Clin. Pharmacol. 5, 2199-2211. doi: 10.18203/ 2319-2003.ijbcp20163262

Seoane, A., Massey, P. V., Keen, H., Bashir, Z. I., and Brown, M. W. (2009). L-type voltage-dependent calcium channel antagonists impair perirhinal longterm recognition memory and plasticity processes. J. Neurosci. 29, 9534-9544. doi: 10.1523/JNEUROSCI.5199-08.2009

Shad, K. F., and Saeed, S. A. (2007). The metabolism of serotonin in neuronal cells in culture and platelets. Exp. Brain Res. 183, 411-416. doi: 10.1007/s00221-0071133-7

Sigala, S., Missale, C., and Spano, P. F. (1997). Opposite effects of dopamine D2 and D3 receptors on learning and memory in the rat. Eur. J. Pharmacol. 336, 107-112. doi: 10.1016/S0014-2999(97)01235-1

Singewald, N., Schmuckermair, C., Whittle, N., Holmes, A., and Ressler, K. J. (2015). Pharmacology of cognitive enhancers for exposure-based therapy of fear, anxiety and trauma-related disorders. Pharmacol. Ther. 149, 150-190. doi: 10.1016/j.pharmthera.2014.12.004

Sitges, M., and Guarneros, A. (1998). Chronic verapamil modifies striatal and frontal cortex dopamine levels. Eur. Neuropsychopharmacol. 8, 105-111. doi: 10.1016/S0924-977X(97)00053-9

Sitges, M., and Reyes, A. (1995). Effects of verapamil on the release of different neurotransmitters. J. Neurosci. Res. 40, 613-621. doi: 10.1002/jnr.490400506

Staneva-Stoytcheva, D., Danchev, N., and Popov, P. (1991). Changes in benzodiazepine receptors of rat brain after long-term treatment with the $\mathrm{Ca}^{2+}$-antagonists nifedipine, verapamil, flunarizine and with the calmodulin antagonist trifluoperazine. Gen. Pharmacol. 22, 1151-1154. doi: 10.1016/03063623(91)90594-V

Staneva-Stoytcheva, D., Danchev, N., and Popov, P. (1992). Long-term treatment with different calcium- and calmodulin-antagonists induces changes in rat brain alpha-adrenoceptors. Gen. Pharmacol. 23, 61-63. doi: 10.1016/03063623(92)90048-O

Staneva-Stoytcheva, D., Popova, J., Mutafova-Yambolieva, V., and Alov, P. (1990). Influence of long-term treatment with the $\mathrm{Ca}^{2+}$-antagonists nifedipine, verapamil, flunarizine and with the calmodulin antagonist trifluoperazine on beta-adrenoceptors in rat cerebral cortex. Gen. Pharmacol. 21, 149-152. doi: 10.1016/0306-3623(90)90611-O

Stayte, S., and Vissel, B. (2014). Advances in non-dopaminergic treatments for Parkinson's disease. Front. Neurosci. 8:113. doi: 10.3389/fnins.2014.00113

Surmeier, D. J., Schumacker, P. T., Guzman, J. D., Ilijic, E., Yang, B., and Zampese, E. (2017). Calcium and Parkinson's disease. Biochem. Biophys. Res. Commun. 483, 1013-1019. doi: 10.1016/j.bbrc.2016.08.168

Tao, L., Liang, M., Wenjun, H., Rui, Z., Miaoling, L., Yan, Y., et al. (2013). The effects of verapamil on SK2 channel in myocardium cells from human chronic atrial fibrillation. Heart 99, A28. doi: 10.1136/heartjnl-2013-303992.086

Tarabova, B., Lacinova, L., and Engel, J. (2007). Effects of phyenilalkylamines and benzothiazepines on Cav1.3-mediated $\mathrm{Ca}^{2+}$ currents in neonatal mouse inner hair cells. Eur. J. Pharmacol. 573, 39-48. doi: 10.1016/j.ejphar.2007.06.050

Taylor, J. E., and Defeudis, F. V. (1984). Inhibition of [3H] spiperone binding to 5HT2 receptors of rat cerebral cortex by the calcium antagonists verapamil and D600. Eur. J. Pharmacol. 106, 215-216. doi: 10.1016/0014-2999(84)90703-9

Tfelt-Hansen, P., and Tfelt-Hansen, J. (2009). Verapamil for cluster headache. Clinical pharmacology and possible mode of action. Headache 49, 117-125. doi: 10.1111/j.1526-4610.2008.01298.x

Thibault, O., Gant, J. C., and Landfield, P. W. (2007). Expansion of the calcium hypothesis of brain aging and Alzheimer's disease: minding the store. Aging Cell 6, 307-317. doi: 10.1111/j.1474-9726.2007.00295.x 
van Zwieten, P., and Pfaffendorf, M. (1993). Similarities and differences between calcium antagonists: pharmacological aspects. J. Hypertens. 11(Suppl. 1), S3-S11.

Wiera, G., Nowak, D., van Hove, I., Dziegiel, P., Moons, L., and Mozrzymas, J. W. (2017). Mechanisms of NMDA receptor- and voltage-gated L-type calcium channel-dependent hippocampal LTP critically rely of proteolysis that is mediated by distinct metalloproteinases. J. Neurosci. 37, 1240-1256. doi: 10.1523/JNEUROSCI.2170-16.2016

Woodside, B. L., Borroni, A. M., Hammonds, M. D., and Teyler, T. J. (2004). NMDA receptors and voltage-dependent calcium channels mediate different aspects of acquisition and retention of a spatial memory task. Neurobiol. Learn. Mem. 81, 105-114. doi: 10.1016/j.nlm.2003.10.003

Yoshimizu, T., Pan, J. Q., Mungenast, A. E., Madison, J. M., Su, S., Ketterman, J., et al. (2015). Functional implications of a psychiatric risk variant within CACNA1C in induced human neurons. Mol. Psychiatry 20, 162-169. doi: $10.1038 / \mathrm{mp} .2014 .143$

Zamponi, G. W., Striessnig, J., Koschak, A., and Dolphin, A. C. (2015). The physiology, pathology, and pharmacology of voltage-gated calcium channels and their future therapeutic potential. Pharmacol. Rev. 67, 821-870. doi: 10 1124/pr.114.009654

Zanos, P., Bhat, S., Terrillion, C. E., Smith, R. J., Tonelli, L. H., and Gould, T. D. (2015). Sex-dependent modulation of age-related cognitive decline by the L-type calcium channel gene Cacnalc (Cav 1.2). Eur. J. Neurosci. 42, 2499-2507. doi: 10.1111/ejn.12952

Conflict of Interest Statement: The authors declare that the research was conducted in the absence of any commercial or financial relationships that could be construed as a potential conflict of interest.

Copyright (c) 2017 Giménez De Béjar, Caballero Bleda, Popović and Popović. This is an open-access article distributed under the terms of the Creative Commons Attribution License (CC BY). The use, distribution or reproduction in other forums is permitted, provided the original author(s) or licensor are credited and that the original publication in this journal is cited, in accordance with accepted academic practice. No use, distribution or reproduction is permitted which does not comply with these terms. 